Vol. 1 No. 2, January 2022

e- ISSN 2809 - 1922 , p-ISSN 2809 - 1914

Available online at:

Journal of Applied

Linguistics

https://journal.eltaorganization.org/index.php/joal/index

\title{
Group Discussion As a Technique for teaching speaking for the tenth grade students in MAN Pinrang
}

\author{
Eka Purwanti \\ STAI DDI PINRANG \\ ekapurwanti077@gmail.com
}

\begin{abstract}
Discussion is one of alternatives technique to help students to formulate their ideas and learn to communicate to the others. The group discussion could be a technique which might be worthy for students, because group discussion is a way where the students have opportunity to express their thinkings to discuss a certain subject, and share information. They can propose arguments, agreements, or disagreements to a topic, and they can also interchange their ideas, feelings, and experiences, and it gives students chances to speak. In this study is aimed to find out the effectiveness group discussion technique for teaching speaking for the tenth grade students in MAN Pinrang in Academic Year 2018/2019. This study was conducted at MAN Pinrang from July $17^{\text {th }}, 2018$ to August $7^{\text {th }}, 2018$. The population of this study was the whole tenth grade students which consist of 280 students, whereas the sample was 64 students which were chosen by random sampling technique. In collecting the data, the writer used oral test to measure the students speaking skill and it is administered twice, namely pre-test and post-test, then the data was analyzed by using SPSS. From the descriptive analysis, it was known that before the treatment the ability of both groups was relatively the same. The two group homogenous, before the treatment began because there was only a slight difference in result between the experimental group and control group. After receiving the different treatments, the result of the experimental group was better than of control group. Based on the statistical analysis, in can be seen that sig ( 2 tailed) $0,001<0,005$ it means that there is a development after treated to the students' speaking ability. From the result above, it can inferred that the group discussion as a technique for teaching speaking for the tenth grade students in MAN Pinrang in academic year 2018/2019 were effective.
\end{abstract}

Key Words: group discussion, technique, students, speaking ability.

\section{Introduction}

Language is important for human being and with language the people can express their idea and communicate easily among people. Since several decades ago, English has become the international language which is learned by many people around the world in order to the people able to enter global communication. Harmer ( 2007 : 11 ) stated that for some people, English is considered as an important language which must be mastered because they must move into a target language community and they need to be able to operate successfully within that community. And many people learn English because they think it will be useful in some way for international communication and travel. 
Realizing its importance in this era, Indonesia's government has released a policy that English is one of the main lessons at schools in our country, because English is not only used for academic purpose, but also for communication among people all around the world. Not only does the government release the policy, but it also has effort to make English easy to be learned by students by having some trainings for the teachers to upgrade the method or approach in teaching English.

EFL learners especially in Indonesia do not get enough their needs in learning English, especially in speaking. The learners may practise English at school, but they cannot use their English to express their ideas, feelings and experiences to others in real communication. This condition makes many students take extra English courses as well as the private ones. Moreover not many of them look for the best course and they have to spend more money and time to take English courses. One of their purpose is improving their ability to speak in English well.

In designing speaking activities or instructional materials for students, the teachers in the classroom must be able to interact with the students and the teachers also should be able to engage the students. According to Tsou ( $2005: 46$ ) studies in language learning have addressed the necessity of classroom interaction or students' oral participation in class where the teacher can interact with the students in many ways. One way which is commonly used to get student's respond is talk. Talk is an essential tool to the teacher's trade. If teachers can do that in the classroom, they will get closer with the students. The effect is the students will feel that they will have some ideas and will try to speak up. That is the point of having interaction to the students, so that the teacher can give motivation and encouraged the students in the lesson.

Discussion is one of the alternatives technique to help students to formulate their ideas and learn to communicate to the others. The group discussion could be a technique which might be worthy for students, because group discussion is a way where the students have opportunity to express their thinkings to discuss a certain subject, and share information. They can propose arguments, agreements, or disagreements to a topic, and they can also interchange their ideas, feelings, and experiences, and it gives students chances to speak.

Based on the description above, the writer chooses this topic "Group discussion as a technique for teaching speaking for the tenth grade students in MAN Pinrang. Since the ability to speak English is a very complex task considering the nature of what is involved in speaking, not all of the students in an EFL speaking class have the courage to speak. Some students are likely to keep silent because they are lack of self confidence, lack of prior knowledge about topics, and because of poor teacher-learner relationship. So that, it could be difficulties the teachers to help the students to improve their speaking ability. The writer assume that the group discussion is a technique which can help the teacher to encourage the students to learn English especially in the teaching speaking. On the other hand, the group discussion gives many contribution to English learning especially in speaking. Because by the group discussion the teachers can help the students to develop their speaking skills and formulates their ideas and learn to communicate to the others.

\section{Method}

The design of this study is quasi-experimental research. In other words, experiment is the way to find the causal relationship between two factors, which are raised on purpose by reducing or eliminating any distracting factors. In this study, "the cause and effect relationship" is the implementation of the group discussion as a technique in teaching speaking and the students' speaking ability in group discussion.

The quasi-experimental which use in this study is the pretest-posttest design with nonequivalent groups. This study is considered as quasi-experimental design because research participants will not be randomly assigned to the treatment and control conditions. According to 
Gall, Walter, et al ( $2005: 259$ ) the pre-test- post-test design with nonequivalent groups is probably the most widely used quasi-experimental design in educational research. It is represented by the following diagram:

\begin{tabular}{|c|c|c|}
\hline $\mathrm{O}_{1}$ & $X$ & $\mathrm{O}_{2}$ ( Experimental groups $)$ \\
\hline $\mathrm{O}_{1}$ & & $\mathrm{O}_{2}$ ( Control groups ) \\
\hline
\end{tabular}

O1 \& O1 : Pre-test

X : Treatment

------ : The broken line indicates that the experimental and control groups are formed randomly.

$\mathrm{O} 2 \& \mathrm{O} 2 \quad$ : $\quad$ Post-test

\section{The Population and Sample}

In this study, the writer choose the tenth year students of MAN Pinrang in academic year 2018/2019 as population. The total number of students in the population is 280 students divided into 8 classes. They are $\mathrm{X} 1, \mathrm{X} 2, \mathrm{X} 3, \mathrm{X} 4, \mathrm{X} 5, \mathrm{X} 6, \mathrm{X} 7$ and $\mathrm{X} 8$. Then, the groups is randomly chosen as the sample of the study in which of them as the member of the population has the equal chance to be included in the sample. It means that no member of the population is excluded from the sample unless by chance. Thus, each the groups' name is written on a piece of paper. The papers is rolled up and mixed well in a tin can. After that, rolled papers is dropped out of the slot one by one.

\section{The Variable of The Study}

Based on the title of the study, the independent variable $(X)$ is group discussion, and the dependent variable (Y) is the students' speaking ability.

\section{Procedure of the Experiment}

Pre-test

Before giving the treatment, the teacher conduct the pre-test for both the experimental group and control group. The pre-test is in oral test form, the students retelling sort story in front of class to measure the students' speaking ability. The pre-test will be conducted by teacher as usual formative test, the scores given by teacher will be gathered as pre-test data.

Treatment

Treatment is given after the pre-test in the experimental group. In this activity, the writer give treatment four times and within each of the treatment the writer give different materials in the meeting. And the step of the treatment are:

- The writer describes what the students should do in groups concerning the task.

- The writer divides the students into some groups, each groups consist of three to five students.

- The writer gives the materials and gives the task to the students

- The students discuss the task in groups.

- The representatives of the groups present the result.

Post-test

Published by English Lecturers and Teachers Association (ELTA)

Copyright (C) 2022, authors 
Post-test is given after the writer conduct the pre-test and treatment. The post-test is in oral test form, in this test the teacher asked the students to performed a speech about their material, to measure the students' speaking ability

\section{The Instrument of The Study}

In this study, the writer used test to know capacities of the students in learning speaking and it is administered twice; namely, pre-test and post-test. Here the pre-test is used to measure the students' speaking ability before they are giving the treatment, and the post-test is used to measure the students' speaking ability after they are given the treatment. To obtain the data, that is the students' ability in speaking, tests is used as the instruments to collect data in this research. The test will be conducted by teacher.

\section{The Techniques of Data Analysis}

In collecting data to complete the study, the writer collect and analyze the data uses the following steps:

a. The writer classified the student's score to measure the students' achievement in pre-test and post-test. A scoring criteria which construct by O'malley and Lorraine ( $1996: 68$ ) to analyze the students' speaking profiency, it include five aspects of speaking profiency which cover the categories of speaking, fluency, structure, vocabulary, and listening.

Table 1. Aspects of Speaking Profiency

\begin{tabular}{|c|c|c|c|c|c|}
\hline $\begin{array}{l}\text { Focus/ } \\
\text { Rating }\end{array}$ & Speaking & Fluency & Structure & Vocabulary & Listening \\
\hline 1 & $\begin{array}{l}\text { Begins to name } \\
\text { concrete objects }\end{array}$ & $\begin{array}{l}\text { Repeats } \\
\text { words and } \\
\text { phrases }\end{array}$ & & & $\begin{array}{l}\text { Understands } \\
\text { little or no } \\
\text { English }\end{array}$ \\
\hline 2 & $\begin{array}{l}\text { Begins to } \\
\text { communicate } \\
\text { personal and } \\
\text { survival needs }\end{array}$ & $\begin{array}{l}\text { Speaks in } \\
\text { single word } \\
\text { utteran-ces } \\
\text { and short } \\
\text { patterns }\end{array}$ & & $\begin{array}{l}\text { Uses } \\
\text { functional } \\
\text { vocabulary }\end{array}$ & $\begin{array}{l}\text { Understands } \\
\text { words and } \\
\text { phrases, } \\
\text { requires } \\
\text { repetition }\end{array}$ \\
\hline 3 & $\begin{array}{l}\text { Begins to initiate } \\
\text { conversation; } \\
\text { retells a story or } \\
\text { experience; asks } \\
\text { and responds to } \\
\text { simple questions }\end{array}$ & $\begin{array}{l}\text { Speak } \\
\text { hesitantly } \\
\text { because of } \\
\text { rephra-sing } \\
\text { and } \\
\text { searching } \\
\text { for words }\end{array}$ & $\begin{array}{l}\text { Uses } \\
\text { predomi- } \\
\text { nantly } \\
\text { present } \\
\text { tense } \\
\text { verbs; } \\
\text { demon- } \\
\text { strates } \\
\text { errors of } \\
\text { omission } \\
\text { (leaves } \\
\text { words out, } \\
\text { word } \\
\text { endings off) }\end{array}$ & $\begin{array}{l}\text { Uses limited } \\
\text { vocabulary }\end{array}$ & $\begin{array}{l}\text { Understands } \\
\text { simple } \\
\text { sentences in } \\
\text { sustained } \\
\text { conversation; } \\
\text { requires } \\
\text { repetition }\end{array}$ \\
\hline 4 & $\begin{array}{l}\text { Initiates and } \\
\text { sustains a } \\
\text { conversation with }\end{array}$ & $\begin{array}{l}\text { Speaks with } \\
\text { occasional } \\
\text { hesitation }\end{array}$ & $\begin{array}{l}\text { Uses some } \\
\text { complex } \\
\text { sentences; }\end{array}$ & $\begin{array}{l}\text { Uses adequate } \\
\text { vocabulary; } \\
\text { some word } \\
\end{array}$ & $\begin{array}{l}\text { Understands } \\
\text { classroom } \\
\text { discussions with }\end{array}$ \\
\hline
\end{tabular}




\begin{tabular}{|c|c|c|c|c|c|}
\hline & $\begin{array}{l}\text { descriptors and } \\
\text { details; exhibits } \\
\text { self confidence in } \\
\text { social situations; } \\
\text { begins to } \\
\text { communicate in } \\
\text { classroom } \\
\text { settings }\end{array}$ & & $\begin{array}{l}\text { applies } \\
\text { rules of } \\
\text { grammar } \\
\text { but lacks } \\
\text { control of } \\
\text { irregular } \\
\text { forms } \\
\text { (e.g.,runned } \\
\text {, mans, not } \\
\text { never, more } \\
\text { higher) }\end{array}$ & $\begin{array}{l}\text { usage } \\
\text { irregularities }\end{array}$ & $\begin{array}{l}\text { repetitions, } \\
\text { rephrasing, and } \\
\text { clarification }\end{array}$ \\
\hline 5 & $\begin{array}{l}\text { Speaks in social } \\
\text { and classroom } \\
\text { settings with } \\
\text { sustained and } \\
\text { connected } \\
\text { discourse; any } \\
\text { errors do not } \\
\text { interfere with } \\
\text { meaning }\end{array}$ & $\begin{array}{l}\text { Speaks with } \\
\text { near native } \\
\text { fluency; } \\
\text { any hesita- } \\
\text { tions do not } \\
\text { interfere } \\
\text { with } \\
\text { commu- } \\
\text { nication }\end{array}$ & $\begin{array}{l}\text { Uses a } \\
\text { variety of } \\
\text { structures } \\
\text { with } \\
\text { occasio-nal } \\
\text { gramma- } \\
\text { tical errors }\end{array}$ & $\begin{array}{l}\text { Uses varied } \\
\text { vocabulary }\end{array}$ & $\begin{array}{l}\text { Understands } \\
\text { most spoken } \\
\text { language, } \\
\text { including } \\
\text { classroom } \\
\text { discussion }\end{array}$ \\
\hline 6 & $\begin{array}{l}\text { Communicates } \\
\text { competently in } \\
\text { social and } \\
\text { classroom } \\
\text { settings }\end{array}$ & $\begin{array}{l}\text { Speaks } \\
\text { fluently }\end{array}$ & $\begin{array}{l}\text { Masters a } \\
\text { variety of } \\
\text { gramma- } \\
\text { tical } \\
\text { structures }\end{array}$ & $\begin{array}{l}\text { Uses extensive } \\
\text { vocabulary but } \\
\text { may lag } \\
\text { behind native } \\
\text { speaking peers }\end{array}$ & $\begin{array}{l}\text { Understands } \\
\text { classroom } \\
\text { discussion } \\
\text { without } \\
\text { difficulty }\end{array}$ \\
\hline
\end{tabular}

The scores of the pre-test and post-test obtain from five categorized of speaking which consist of speaking, fluency, structure, vocabulary, and listening. The range of each categorized score is 1-6, the students' scores gets from the sum of the total score of these five categorized multiplied by 100 , and divided by the total of questions.

b. After scoring the data, the writer collecting the data and processed them statistically. The writer used statistical computation to analyze the data from control group and experimental group. After getting the result, the writer continued to determine the hypothesis by using independent sample t-test because the writer would like to find out the significant difference between the experimental group and control group. The writer used SPSS for windows release version 16.0 to determine the hypothesis and standard normality. To know the standard normality, the writer used alpha of significance is $5 \%$.

\section{Data Analysis \\ Description Analysis \\ Analysis of the pre-test}

Before treatment, the teacher gave pre-test to students. The pre-test was conducted on July 17, 2018 in experimental group and control group was conducted on July 17,2018. It was followed by 64 students; consist of 32 students of X2 as a control group and 32 students of X6 as an experimental group. In this pre-test, the teacher used oral test, where the teacher asked the student to retelling sort story. The pre-test was given to the control and experimental group. 


\section{Analysis of Treatment}

Treatment was conducted four times, from July July 17 - August 7, 2018 and the schedule are:

Experimental Group :

- Pre-test, July 17, 2018.

- $\quad$ Treatment I, July 20, 2018.

- Treatment II, July 24, 2018.

- $\quad$ Treatment III, July 27, 2018.

- $\quad$ Treatment IV, July 31, 2018.

- Post-test, August 03, 2018.

Control Group :

- Pre-test, July 18, 2018.

- Treatment I, July 21, 2018.

- Treatment II, July 25, 2018.

- $\quad$ Treatment III, July 28, 2018.

- $\quad$ Treatment IV, August 01, 2018.

- Post-test, August 04, 2018.

The purpose of the treatment was to enrich student' speaking ability. In the treatment, the experimental group used the group discussion method and the control group used telling sort story. This aim to improved students' speaking ability.

\section{Analysis of Post-test}

In the post-test, the teacher made a review of all material from treatments. The post-test was similar with the pre-test. However, the post-test was given after the treatment did in teaching speaking by using group discussion method. The teacher used oral test. In this test, the teacher asked the students to performed a retelling sort story suitable with the material which was given in the previous meeting. Post-test used to know the ability of the students after they got the treatment in two different media. The post-test was conducted on August 03, 2018 in experimental group and control group was conducted on August 04, 2018. It was followed by 64 students; consist of 32 students of $\mathrm{X} 2$ as a control group and 32 students of X6 as an experimental group. In this post-test, the teacher used oral test, where the teacher asked the student to retelling sort story. The post-test was given to the control and experimental group.

\section{Research Finding}

The purpose of the test was to know students' speaking ability by using group discussion as a technique for the tenth year students of MAN 1 Pinrang, in the Academic year of 2018/2019. The writer anayzed the data of pre-test and post-test by using t-test formula, the result shows that the coefficant is $\pm 3,593$. It means that there is a significance increase in teaching speaking by using group discussion as a technique.

In the pre-test the average score of the experimental group and control group were 61,43 and 61,37. From the pre-test it could be said that the ability of both groups was relatively the same. After they received the treatment the average scores of the experimental group and control group were 76.09 and 70.06 .

From the explanation above it can be concluded that the two groups homogenous, before the treatment began because there was only a slight difference in result between the experimental group and control group. After receiving the different treatments for both groups, the result of the experimental group was better than of control group. 
As seen from the significance difference between the experimental group and the control group, it can be concluded that the group discussion as a technique for teaching speaking for the tenth grade students of MAN Pinrang in academic year 2018/2019 were effective.

\section{Conclusion}

Based on the result of the data analysis the conclusion of this study are group discussion could be an effective technique for teaching speaking to improve the students' speaking ability, it was supported by the significant difference in the result of post-test between control and experimental group and the teaching learning activity by using group discussion technique showed a positive effect on the students' achievement. The students' speaking ability in the class by using group discussion technique was good. It means that group discussion technique could possibly be used to improve the students' speaking ability.

\section{REFERENCES}

Arikunto, S. (2010). Prosedur Penelitian Suatu Pendekatan Praktik. Jakarta: Rineka Cipta.

Barkley, E. F., Cross, K. P., \& Claire, H. M. (2005). Collaborative Learning Techniques. San Francisco: John Wiley \& Sons, Inc.

Best, J. W. (1981). Research in Education (4 ed.). New Jersey: Prentice Hall, Inc.

Forsyth, D. R. (2010). Group Dynamics (5 ed.). USA: Wadsworth Cengage Learning.

Horn, T. S. (2008). Advances in Sport Psychology (3 ed.). United States of America: Human Kinetics.

Murcia, M. C. (2001). Teaching English as a Second or Foreign Language (3 ed.). United Stated: Heinle \& Heinle.

O'malley, J. M., \& pierce, L. V. (1996). Authentic Assessment for English Language Learners: Practical Approaches for Teachers. Virginia: Addison-Wesley Publishing Company.

Sethi, Anjanee, \& Adhikari, B. (2010). Business Communication. New Delhi: Tata McGraw Hill. Ur, P. (1981). Discussions That Work. London: Cambridge University Press. 